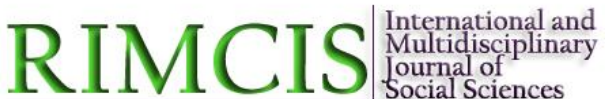 \\ Social Sciences}

\section{Hipatia Press}

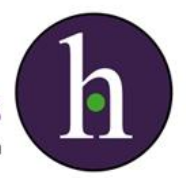

Instructions for authors, subscriptions and further details:

http://rimcis.hipatiapress.com

\title{
The Impact of Road Accidents to the Community of Iringa Municipality: Challenges in Reducing Risks
}

Evaristo Haulle ${ }^{1}$, Marwa Kisiri ${ }^{1}$

1) Mkwawa University College of Education, Tanzania

Date of publication: November $30^{\text {th }}, 2016$

Edition period: November 2016 - February 2017

To cite this article: Haulle, E, \& Kisiri, M. (2016). The Impact of Road Accidents to the Community of Iringa Municipality: Challenges in Reducing Risks. International and Multidisciplinary Journal of Social Sciences, 5(3), 253-280. doi: 10.17583/rimcis.2016.1880

To link this article: http://doi.org/10.17583/rimcis.2016.1880

\section{PLEASE SCROLL DOWN FOR ARTICLE}

The terms and conditions of use are related to the Open Journal System and to Creative Commons Attribution License (CC-BY). 


\section{The Impact of Road Accidents to the Community of Iringa Municipality: Challenges in Reducing Risks}

Evaristo Haulle Mkwawa University
Marwa Kisiri

Mkwawa University

\section{Abstract}

This paper examines impact of Road Accidents on community socio-economic activities in Iringa municipality. It assumes that accident as any disaster adversely affects people, property and environment. The paper employed questionnaire, interview, observation and documentary search for data collection. The study found that road accidents on-site conditions were caused by poor infrastructure, overloading of vehicles, law impunity, inadequacy of relevant laws, corruption, negligence of drivers, lack of road safety education and road traffic signs. Road accidents caused loss of lives, increase of dependence, destruction of property, increase of poverty, injuries and permanent disabilities. Provision of training to drivers, serious enforcement of the laws, provision of education to road users through public agitations, posters and television broadcasts, introduction of ad hoc inspection of road quality and transport facilities were some of the techniques used to curb the risk. Generally, road accidents caused a great loss of human, physical and natural resources. The intervention is on on-site conditions while very little attention is put on the root causes. It is recommended that, in addressing this human induced disaster the government in collaboration with other stakeholders should focus on the root causes in a participatory manner to bring community equity hence sustainable development.

Keywords: road accidents, community, Iringa municipality, disaster 


\section{El Impacto de los Accidentes de Tráfico en la Comunidad del Municipio de Iringa: Retos en la Reducción de Riesgos}

Evaristo Haulle

Mkwawa University

\author{
Marwa Kisiri \\ Mkwawa University
}

\section{Resumen}

Este artículo examina el impacto de los accidentes de tráfico en las actividades socioeconómicas de la comunidad en el municipio de Iringa. Se asume que los accidentes, igual que cualquier otro desastre, afecta negativamente a la población, a los bienes y al medio ambiente. Para la recolección de datos del artículo se utilizaron cuestionarios, entrevistas, observación y revisión de documentos. Entre las condiciones en el lugar de los accidentes, la investigación halló que éstos eran causados por infraestructuras deficientes, exceso de carga de los vehículos, impunidad legal, leyes relevantes inadecuadas, corrupción, negligencia de los conductores, falta de educación vial y de señales de tráfico. Los accidentes de tráfico provocaron pérdida de vidas, aumento de la dependencia, destrucción de bienes, aumento de la pobreza, heridas y discapacidades permanentes. Algunas de las técnicas utilizadas para reducir los riesgos fueron facilitar formación a los conductores, una aplicación rigurosa de la ley, facilitar educación a los usuarios de carreteras a través de difusión pública, pósters, y emisiones televisivas, inspecciones a propósito para comprobar la calidad de las carreteras y facilitar medios de transporte. Generalmente, los accidentes de tráfico causaron grandes pérdidas de recursos humanos, físicas y naturales. La intervención se da sobre las condiciones donde tienen lugar los accidentes, mientras que se presta poca atención en la raíz de las causas. Para abordar este desastre humano inducido se recomienda que el gobierno en colaboración con otros agentes se centren en la raíz de las causas de una manera participativa a fin de conseguir equidad comunitaria y consiguientemente desarrollo sostenible.

Palabras clave: accidentes de tráfico, comunidad, municipio de Iringa, desastre 


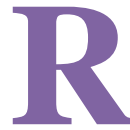
oad accidents are one of the major issues in human induced disasters in the world as the car crashes are the leading road killer. About 1.3 million people die and 50 million others are injured on road accidents annually (Raffo \& Bliss, 2012). By the year 2030, road traffic injuries are predicted to be the fifth leading cause of death worldwide and the seventh leading cause of disability (Taft, 2002). According to Wisner et al. (2005), developing countries are more affected by road accidents than developed ones. The severity of road accidents also differs over space and time; for instance, road safety situation in East Asia and Pacific is better than that of Sub-Saharan Region with the death rate of 18.5 per 100000 people in 2010 (World Bank, 2014). There is a great disparity in road traffic death rates or road injuries are higher in African region with the number of 24.1 per 100000 people and lower in Europe with rate of 10.3 per 100000 people. It is also reported that in terms of means of transport, world road traffic death occurs among Motorcyclists (23\%), pedestrians (22\%) and Cyclists (5\%) who are vulnerable road users, with $31 \%$ of the death among car occupants and remaining (19\%) among unspecified road users (WHO, 2013). Literature show that road accident fatalities increase by $42.3 \%$ while road injuries rise to about $98.2 \%$ (Robertson et al., 2009). Statistics show that $78.84 \%$ of road accidents are caused by human behavior specifically poor adherence to traffic rules and regulations. For instance, in India, it is relatively easy for people to get a license without proper driving skills (Chakrabarty, Gupta \& Bhatnagar, 2013).

Tanzania is of no exception in this case. It is among the highly affected developing countries in East Africa and Africa in general (Chiduo \& Minja, 2001). In 2010, the country had the road traffic death rates of 22.7 per 100,000 (World Bank, 2014). The road accidents are rising day after day; for instance, in 1977-2008 there was about 379, 699 accidents with 48, 754 fatalities and 347, 657 people injured while leaving substantial damages to property. In 1977 there was 6,410 while in 2008 the number tripled and made a total of 20, 615 crashes per annum. In 2009, 2010 and 2011 the accidents continued to increase to $22,739,24,665$ and 22,508 events per annum respectively. The fatalities have increased tremendously despite the intervention measures taken. For instance, the fatalities almost doubled in four years from 2011 to 2014 where it reached 829 from 469. Despite the 
facts that many organs both government and non-governmental associations have taken several initiatives, yet the problem still persists causing socioeconomic malfunctioning. According to the Daily News published on Thursday $9^{\text {th }}$ February 2012 in 2010 the government experienced a loss caused by road accidents in monetary terms amounting to 849.91 billion shillings. Again, Chiduo and Minja (2001) reported that road accidents cost the government about 10 billion of Tanzanian Shillings (equivalent to Seven million US Dollar) in the 1990s.

Several studies like MøllerDanø (2004), Peden et al. (2004), Mnzawa (2013), Medi (2014), Boniface et al. (2016), have associated the problem with poor infrastructure, drunkenness, vehicle overloading, negligence of drivers and riders and unqualified drivers. These all are onsite conditions that cannot be resolved without looking at the root causes of such problems. Why is there disparity of development and how these impacts affect much the poor than the rich is an issue of not only thinking about the physical conditions underpinning the community (Oliver-Smith \& Hoffman, 1999) but also the underlying causes through the dynamic pressures that, in fact, are related to the institutional framework that governs the ideas and ideologies of the society. This is what is considered as the common sense, the sense of the ruling class which is not articulated by such studies.

\section{Methodology}

The study was carried out in Iringa municipality. It is located in Iringa District in Iringa Region. It is situated around latitude $7^{\circ} 48^{\prime} \mathrm{S}$ of Equator and longitude $35^{\circ} 43^{\prime} \mathrm{E}$. The altitude is between 1,560 and 2000 meters above sea level. The Municipality covers an area of 176.987 square $\mathrm{km}$. The municipality is round bordered by Iringa District Council with exception to the Southern East where the Municipality is bordered by Kilolo District. The area was chosen as it is transverse by the transcontinental road from Cape town to Cairo. It is located in the area with the highest flow of traffic in Tanzania. It connects southern highlands of Tanzania which is a quarter of the country and directly connects with Zambia, Malawi and Congo. Failure of Tanzania Zambia Railway Authority (TAZARA) made this road to be the main mode of transport. The study employed both qualitative and 
quantitative research approaches, where qualitative research approach was employed to explore people's understanding on the subject under study (Cormark, 1991; Singh, 2007; Dawson, 2007; Creswell \& Plano, 2011; Kothari, 2014). The study employed case study design for it flexibly allows using both qualitative and quantitative research approaches on a single unit to produce an in-depth description that is rich and holistic; it also allows multiple data collection methods (Ary et al., 2010). The study employed interview to collect data from Tanzania Revenue Authority (TRA), Tanzania Roads Agency (TANROADS), Surface and Marine Transport Regulatory Authority (SUMATRA), motorcycle riders association, Police and Medical officials. The study employed a multi stage random sampling technique to obtain motorcycle riders, vehicle drivers, the households and pedestrians for questionnaire administration. These were selected due to the fact that these key players and users of transportation facility. Furthermore, the study observed the nature and quality of infrastructure, motor vehicle, motorcycle and road traffic signs. To complement primary data, documentary review was used to collect secondary data. The collected data were analyzed using thematic method for the qualitative data and Statistical Package for Social Science (SPSS) software Version 20 was used to analyze qualitative and quantitative data. Microsoft office (Excel) was also used to plot some charts, tables, and figures. The analysed data were then presented in form of charts, figures, tables, map, and text.

\section{Results and Discussion}

The study found out that there were several hot spots for accidents in Iringa municipality. The points that were pointed by SUMATRA and Police officials were Kihesa road, Msikitini in Mkwawa road, Kiwandani area in Ipogolo and Mlandege area in Kalenga road (See Figure 1).

Accidents, as any other man-indused disasters lead to malfunctioning of the society to the extent that its repair is difficult (URT, 2004; Haulle, 2007); hence, economic burdens. For example, in 2007 the Bureau of Industrial Cooperation (BICO) under the University of Dar-es-Salaam estimated that road accident cost the nation $3.4 \%$ of its Gross Domestic Product (GDP) which was equal to 508 billion in 2006 (URT, 2009). These data indicate 


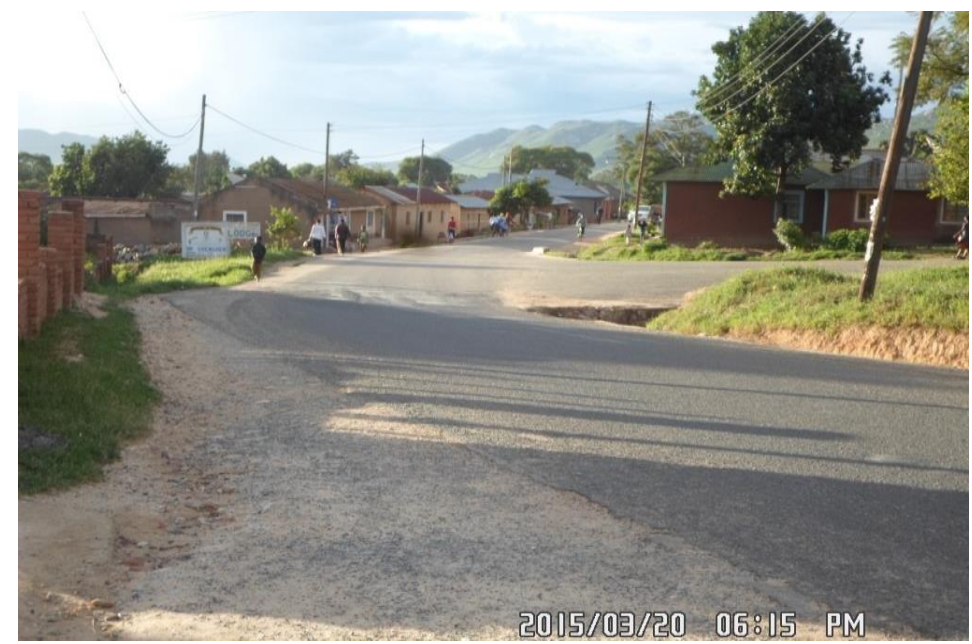

Figure 1. Msikitini area along Mkwawa road is one of the areas identified as accident hot spot for road accidents as the area has no any road traffic sign and its junction is in steep terrain and corner. The road is narrow without pedestrians' path as per Highway Code, of 2008 and the minimal standards as described by Murphy (2011). This increases risks to drivers and other road users

Table 1

Tanzania Road Accidents for the period 2007-2012

\begin{tabular}{ccccc}
\hline Year & $\begin{array}{c}\text { Number of } \\
\text { Accidents }\end{array}$ & $\begin{array}{c}\text { Annual } \\
\text { Increase \% }\end{array}$ & Death & Injuries \\
\hline 2007 & 17,753 & & 2594 & 16308 \\
2008 & 20,615 & 0.4 & 2905 & 17861 \\
2009 & 22,739 & 16 & 3223 & 19263 \\
2010 & 24,665 & 10.3 & 3981 & 20656 \\
2011 & 23,986 & 8.5 & 3981 & 20802 \\
2012 & 23,578 & -2 & 3969 & 20111 \\
\hline
\end{tabular}

Source: Traffic Police- Iringa 2015 
how road accidents in recent years are causing malfunctioning of the society (Table 1). The projection shows that by 2020 road accidents are expected to be the third leading cause of death (UN-habitat, 2007). The problem of road accidents has become chronic (Chiduo \& Minja, 2001).

The findings show that the overall road accidents in Iringa Municipality are increasing because of the increase in population and number of vehicles especially motorcycles. About $94.8 \%$ of the household responded that the accidents are increasing in recent years. This is similar to the data given by the police and SUMATRA which show that the situation in Iringa is more or less the same as the situation country wide. About $25 \%$ of the household respondents reported that motorcycle crashes are now the leading causes of deaths, followed by car accidents. The same was reported in the Referral Hospital, Central Police Station and TANROADs. The Regional Traffic Officer (RTO) reported that deaths caused by road accidents are adversely affecting youth group between 15-35 years old, whereby males are more affected compared to females. This increase is rarely connected to the decline of the use of railway in transporting heavy cargo. There is increase use of trucks for shipping heavy cargo while using the same roads with passenger's vehicles and light load.

The data show the rising trends of road accidents beyond the normal estimate; road accidents are doubled every month (Chiduo \& Minja, 2001). The magnitude and effects of road accidents accelerate an increase in the number of fatalities and injuries. The results go in line with the present sources as the municipality is currently faced with increase in number of road accidents. This was justified by data collected via interview, questionnaire, and documentary reviews.

\section{Causes of Road Accidents}

The study showed that the accidents are caused by individual driver's behavior, mechanical error and physiographic conditions of the mode of transportation though they can be further categorised (see Figure 2). The study also found that many drivers are driving beyond the legally accepted speed. The interview conducted with TANROADS, SUMATRA, the police and motor cycle riders association officials; and questionnaire responses 
revealed excessive speed to be the main cause of road accidents in Iringa Municipality. This finding concurs with several other studies (see for example, Lay, 1986; Peden et al., 2004; Chiduo \& Minja, 2001; Richard, 2004; WHO, 2013; Bashaya, 2015; Majinge \& Mwafongo, 2015). Speed Radars have been in use to control the crisis, yet majority drivers are speeding up. It was also noted that $50 \%$ of drivers acknowledge over speeding. The reasons given to justify their malpractice, among others, were that drivers rush to save time in order to have more time to rest, to scramble for passengers to increase their income by making more trips for commuter bus or competing with others to get more passengers along the route. Over speeding was also attributable to low salaries paid to drivers, thus, it acts as a remedy for earning more income. This was possible due to the fact that over speeding helped the drivers to get more passengers ahead or have more routes in a day so as to make more money for themselves. This is also equated to what Wisner et al. (2005) and Haulle (2007) present as the root cause for disaster according to crunch model.

Unequal distribution of resources in the economy is another underlying cause that through propulsive forces the on-site conditions are manifested. The state does not question why these people are breaching the law while they are aware. The relationship between the vehicle owners, drivers and the state is very important in relation to the division of income and production relations (Haulle, 2014). It should be noted here that there is nothing like individual behavior because human being is the result of social creation (Shivji, 2005). Whatever is done by human being is a result of the social construct, it is the interpretation of the material facts (Haulle, 2014).

The data show that some accidents are caused by the nature of infrastructure.Many roads in the municipality are full of pot-holes with limited road traffic signs (see Figure 3). It was also observed that many roads are too narrow to guarantee safety of different road users; and, some of them are very close to houses to the extent that they cannot offer packing lots for emergency. The study through the interview conducted with taxi and commuter bus drivers and the motor cycle riders revealed poor quality of roads as source of road accidents (see Figure 3). This finding is compatibly supported by the study by Thagesen (2005), SUMATRA (2007), Ministry of Road Transport and Highway Government of India (2011), and Majinga and 


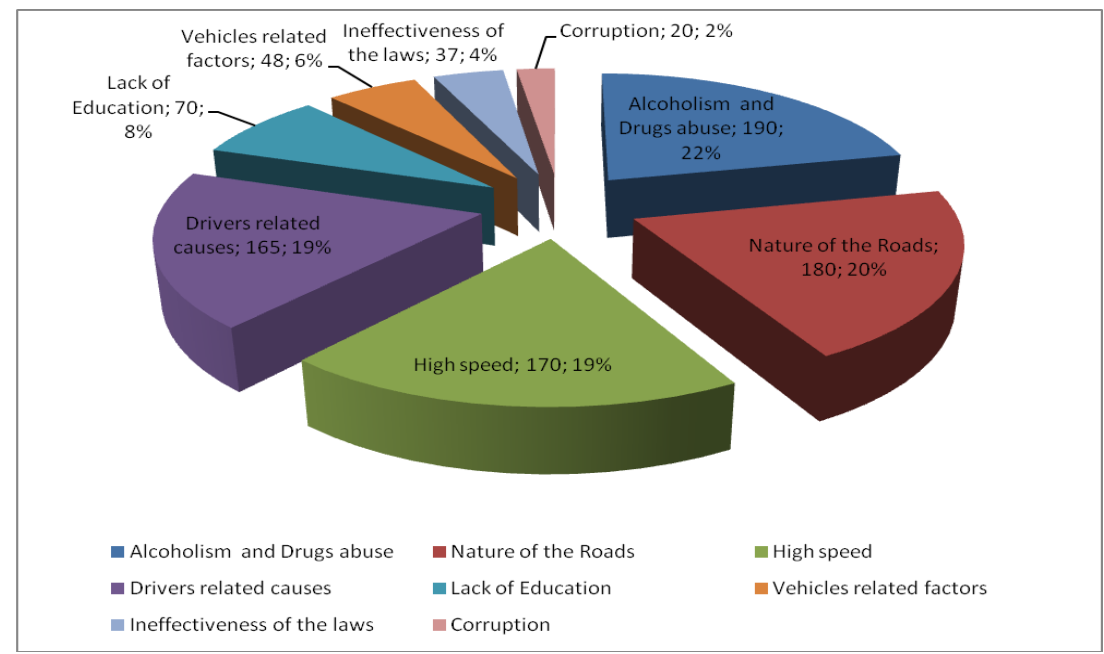

Figure 2. The onsite and propulsive forces for road accident in Iringa Municipality Source: Field survey

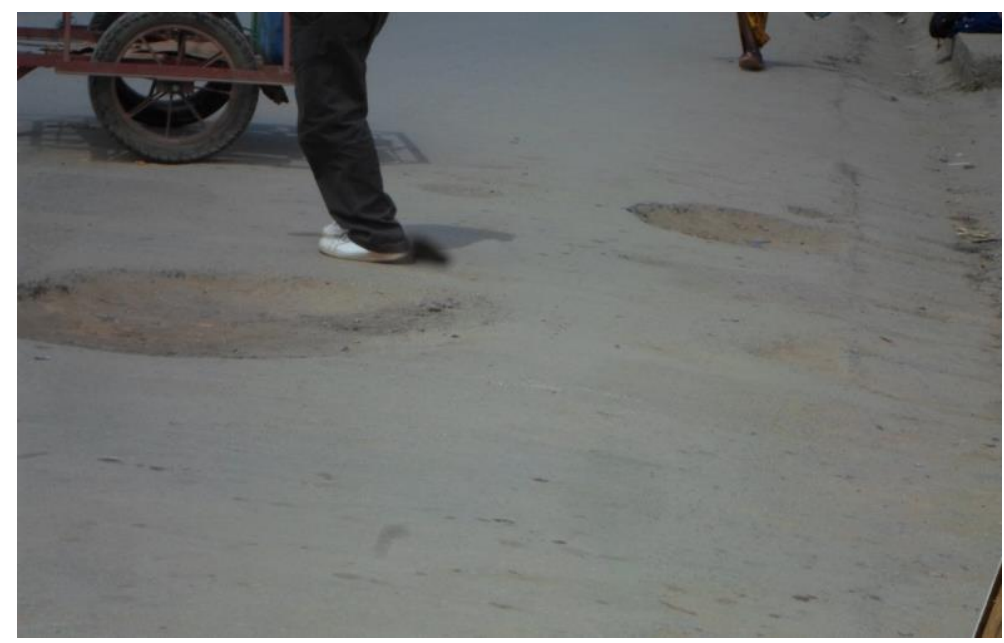

Figure 3. Some of the existing pot-holes on roads that have potential of causing accident. These are pot-holes found at the main bus stand entrance of the Iringa municipality. 
Mfyongo (2015) which also report thatthe condition of road affects the occurrence of road accidents, poor quality of road have a greater chance of causing road accidents. Modern infrastructure is highly ranked in reducing numbers of road accidents when compared to poor ones, hence, when rehabilitation of roads is done, care should be taken to see to it that they are in line with standards in place and modern ones.

The study revealed the problem of drivers and motorcycle riders of drinking before or while driving to be among the major sources of road accidents in Iringa municipality. The interview conducted with the TANROAD officer, SUMATRA officer strongly accused the drivers of Driving Under Influence (DUI) of alcohol. They always take bamboo juice which is produced in Iringa abundantly while others are taking spirits which are popularly known as viroba that lead to road accidents. One of the Police officers was quoted saying:

Most of the youth opt to be bodaboda riders as a means of income. However, most of them drive under influence of alcohol while they are not aware of the traffic safety regulation.

On a similar note, the RTO was quoted saying that:

Most occurrences of road accidents in Iringa Municipality were resulted by ulanzi (bamboo juice) which affects many pedestrians. Alcohol and drug also impair the skill and judgment necessary for driving.

It was noted that spirits popularly known as viroba is a form of alcohol that is mixed with water and drank before or while diving. Similarly, Peden et al. (2004) classify drinking and driving as one of the five principal risk factors in road safety. Moreover Chiduo and Minja (2001), Sauter et al. (2005), Komba (2006), SUMATRA (2007) and Mnzawa (2013) identify alcoholism as source of road accidents; they argued that drunkenness is a serious problem and among the leading causes of road accidents and that many drivers are DUI.

The study reveals that there is a serious weakness of road traffic Act of 1973, where the Act is not only old but also inappropriate for the current 
situation. For example, the offences charge ranges from $10,000 /=$ to $30,000 /=$ and recommends that the penalty of fine should not exceed Tsh. 50,000/= (equivalent to $\$ 25$ ). The Act directs that the fine charges related to false provision of information during license acquisition should be $10,000 /=$ or the term of imprisonment not exceeding 2 years, thus, this friendly penalty influences drivers to repeat offences as it is cheaply affordable. This finding was supported through interview conducted with the SUMATRA, Police officials, and TANROADS officers as they had this to say:

The fines and penalties imposed by the police are too small to end the problem, because drivers can afford it many times without change in the behavior developed.

This finding is supported by several studies that considered that the fines provided are too small, hence, accelerated accident incidents (URT, 1993; Sauter et al., 2005; Komba, 2006; SUMATRA, 2012; Mnzawa, 2013). The government must show commitment in enforcing the laws and amending the weak ones to reduce rate of road accident incidents. However, it was noted that the increase in fines increased the corruption. For instance, when the fine increased from 20,000 Tsh to 30,000Tsh the amount given to traffic police increased from around 5,000/= to10,000/=. This at the same time accelerated over speeding as drivers could give bribe to traffic police quite easily.

Again, the finding shows that on one hand, many road accidents are sometimes caused by vehicle overloading since overloaded vehicle tends to lose balance and stability leading to accident incidents. On the other hand, the overloaded vehicles destroy roads as they exceed the road cargo capacity. SUMATRA (2007), Pinard (2010) and Medi (2014) assert that the overloaded vehicles tend to reduce the ability to withstand disturbances and reduce the driver's confidence while driving. The deadly car crush of Majinja bus versus the Semi-trailer which occurred in Iringa region and claimed the lives of more than 40 passengers in March 2015 is the evidence to justify (see Figure 4). The most important challenge is whose vehicles are these? Are they owned by the drivers? What is the relation in production? What is the relationship between the vehicle owners and the state? These are among the biggest questions in curbing the road accidents that are not asked when trying to mitigate this technological disaster. 


\section{Haulle \& Kisiri - Road Accidents Disaster}

The study found that insufficient education is a factor contributing to road accidents. In this aspect, the findings showed that many people do not have basic road safety education. Many pedestrians, motor cyclists and drivers do not adhere to the road safety rules and regulations in place as a result of lack of awareness. For instance, about 30\% of the questionnaire respondents supported ignorance of the people to be the source of road accident. The interview conducted with TANROADS and SUMATRA officials, and taxi drivers revealed that many people are not well educated on road safety issues. The results are supported by URT (1993), and Mnzawa (2013) who argue that there is no coordinated system of safety education, and it has never been a compulsory part of school curricula in Tanzania.This limited access to road safety education has a far-reaching impact as it hugely contribute to the road accident incidents. It was also evident that in order to reduce the severity of this man-made technological disaster, there is need to mainstream road safety in school curricula. However, Haulle (2012), had argued that the demand of mainstreaming everything in curricula makes the curricula to be not stable. Further it was also noted that there is a serious weakness in the formulation of the curricular. The curricular lacks clear societal objectives that needed to be fostered (Haulle \& Rugumamu, 2015).

Moreover, the study further found that many roads in Iringa municipality lack adequate traffic signs a situation that is said to increase the risks to road accidents. In some areas traffic signs present direct wrongly or rather present false information when compared to what actually exists in practice. The study, again, found that about $97.5 \%$ of the household respondents indicate that inadequate road traffic signs increase the propensity to road accidents. Many roads have no Zebra crossing signs and other important warning and directing signs to road users. In this regard, it was further noted that in risky areas where there is no road signs the rate of road accident incidents was high (Figure 1). Moreover, in some instances the signs put in place do not represent what has been in practice. For instance, at the exit from the Iringa central bus stand to the Dodoma road junction road signs are confusing. For example it was noted that the entry sign was shown on the one way exit from Iringa Bus terminal which was prohibited to be used as entry in practice. According to Sauter et al. (2005), Komba (2006) and Mnzawa (2013), in addressing this issue the government should build new and modern road 
traffic signs. However, the installation of these road traffic signs should go in line with provision of the state vision, mission and objectives for sustainability.

\section{The Socio-economic Impacts of Road Accidents to the Iringa Community}

Tanzania has experienced three deadly transportation disasters in recent years. Firstly, the events of MV Bukoba in Lake Victoria in May 1996 where more than 600 people died. Secondly; the central line train accident at Msagali- Igandu in Dodoma in June 2002 where more than 300 people lost their lives. Lastly; MV Spice Islander where $250-2000$ people are said to have lost lives at Nungwi Unguja -Pemba in the Indian ocean in September 2011 (Mubiru, 2013). Spice Islander is considered to be the world worst maritime disaster ever. Others include that of 1973, where 43 people were killed on the spot when the reckless driver dumped the bus into the river Makumila in Arusha region. Similarly, in 1991, 29 people were killed when minibus had a head-on collision with a lorry in Dodoma and 37 people died when the Super Star bus overturned. Again, in 1992, 27 people died leaving 23 others injured at Mzambarauni in Tanga region (URT, 1993).

Wisner and Gaillard (2009) show that all accidents that involve massive killing are the only events considered in the disaster management according to the international data base, EMDAT, of the Centre for Research on the Epidemiology of Disasters base in Belgium. However, the events that are involving a few people in total are causing malfunctioning of the society quite severely than the single event (Wisner \& Gaillard, 2009). This magnitude has to do with the degree of attention and assistance given to the situation that demands more than local or national resources and capacities.

By contrast, researchers in Latin America have used DesInventar, a data base to catalogue for Colombia alone more than 19,000 small and moderate events that took lives, destroyed assets and infrastructure in the period 19712002. A total loss, in terms of finance was greater than all of the high profile disasters by affecting the country when taken together. For instance, EMDAT recorded only 97 disasters in Colombia for that period. A few of 19,000 
small and moderate events made it into the national press in Colombia. This situation might be happening in Tanzania and Iringa in particular.

The study found that road accidents have increased the number of fatalities in the municipality, for instance: in 2011, 2012, 2013, 2014 fatalities were $469,783,681$, and 829 , respectively. The situation seems to be even worse in 2015 because according to medical data from Iringa Referral Hospital within two months: January and February, there were 119 fatalities.

The interview conducted with TANROADS and Police officials showed that road accident is one of the main causes of deaths in Iringa region. Similarly, WHO (1986), Rodriguez (2005), and SUMATRA (2012) showed that about 1.2 million of people are killed in road accidents annually. Moreover, according to UN-habitat (2007), about 3,242 people die daily of road accidents worldwide. Dedicated efforts, resources and determination are highly needed to reduce death toll to save human kind.

Many personal and public properties are damaged as a result of road accidents; for example, means and modes of human transportation; water, telephone and electric transmission lines, houses, crops and all other properties in the vicinity due to road accidents. The oil spills due to road accident is increasing risk for human safety and security as they may destroy the quality of bitumen roads and they become slippery. It was confirmed that there is always destruction of road system due to fire outbreak after accident. Other studies showed that people's properties are continuously destroyed, leading to impoverishments of local economy, employment opportunities and physical disabilities (URT, 1993; Komba, 2006; Ministry of Road Transport and Highways Government of India, 2011; Sauwa, 2015).

The study further noted the greater impact of road accident is a distortion of economy since road accidents lead to destructions of properties like motor vehicle, motor cycle which is the source of income. The interview conducted with SUMATRA revealed that the government loses a lot of income as it fails to collect income in form of taxes and licenses. The government is also losing a lot of money in importing medicines and doctorsfor medical treatment of the injured people. However, it was difficult to establish the maintenance cost due to unconsolidated and unharmonised insurance cost incurred per annum as compensation involved in accidents. It was also noted that to avoid bureaucracy some of the crashes are not registered. Some 
involved parties reconcile and, thus, maintenance and so compensation are settled informally. According to URT road traffic accidents cost the government about 235 billion per year; statistically this reduces the government's capacity to support its people. This means that even what is provided is far behind from what is happening on the ground. As opposed to Tanzania, Peden et al. (2004) states that road traffic injuries cost European Union countries $€ 180$ billion annually. This is 30 times the budget of Tanzania and twice the annual budget for development activities in EU countries. The government spent a lot of money for roads maintenance caused by accidents. The Ministry of Road Transport and Highway Government of India (2011) argued that many resources are either drained or curtailed as a consequence of the loss of life as an income earner or property due to road accidents.

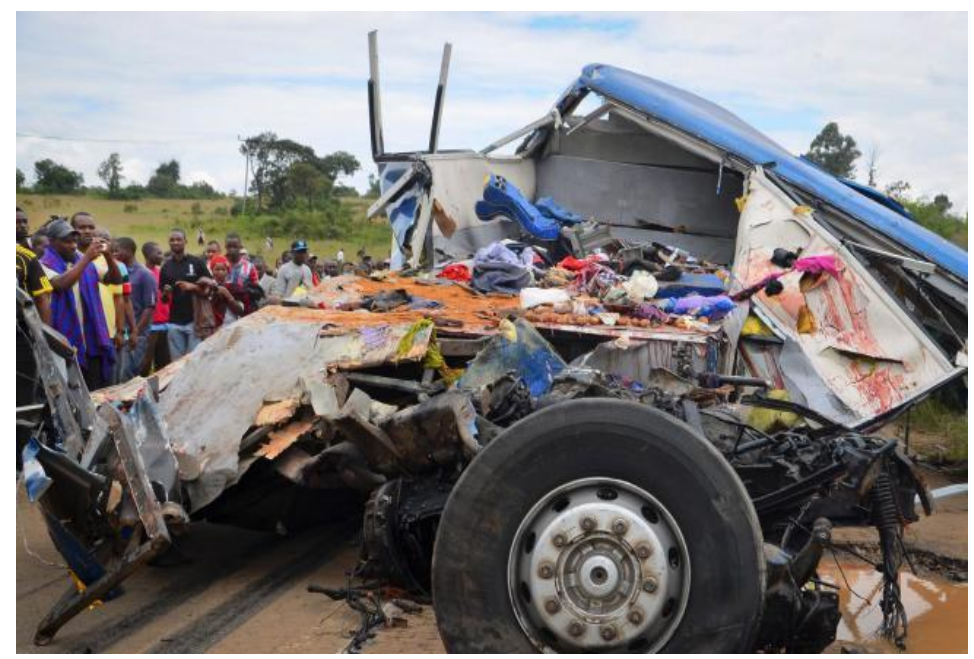

Figure 4. A Lorry and a Majinja bus collision in Iringa Tanzania, killing 42 people. Note: the bus was destroyed beyond repair.

It was identified that road accidents caused the suffering of many people due to injuries and permanent mark of disabilities. About $24 \%$ of the respondents showed that many people are injured and some of them acquire permanent life scars or disabilities as a result of road accidents (Figure 2). 
Nevertheless, the UN-habitat (2007) adds that more than 75\% of road accidents causalities are among economically youth adults. This is because according to Malthusian theory of demography, youth are more mobile than children and elders. Thus, the affected people become a burden to the economic growth of the country since productive people are turned to unproductive increasing the dependence ratio. The interview with the medical officials revealed that many hospitalized people suffer from severe injuries leading to handicaps, depression and psychological disorders. Some of them are suffering from trauma because they have turned to dependents.

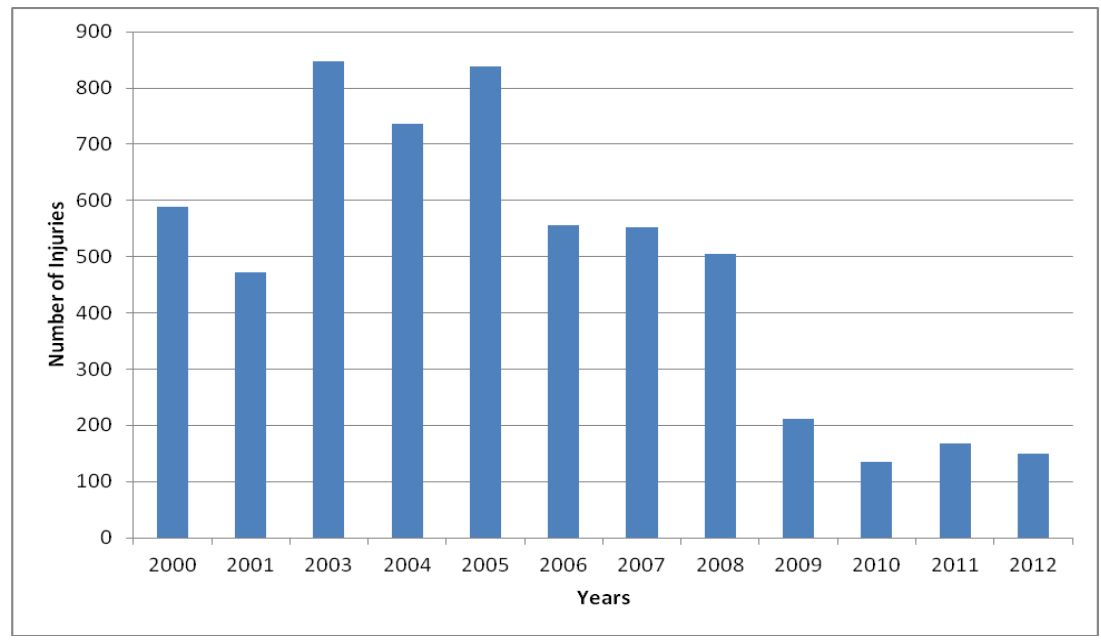

Figure 5. Road Traffic Injuries in Iringa

Source: Traffic Police

*Even though the injuries seem to decline it increased in recent years.

On the other hand, road accidents to a large extent increase number of dependents especially when the workforce age groups die, those who are usually left widows and orphans find life difficult. One child was quoted saying;

Ohh Father, you are dead! Who will feed us? Ohh God this is the end of my studies, see how mom can do this...! 
European Federal Road Victims in 1993 presents that the impacts of road accidents victims is numerous and diverse, as both mental and physical; job absence and disability adversely affect people's livelihood and productivity. Furthermore, the study identified that $90 \%$ of the road accidents victims, and $35 \%$ of the families have victims who has developed disabilities, and half of the cases are permanently declined in quality of life and/or standard of living. The burden of crashes is borne not only by those directly involved in road accidents but also their families. This means that struggle against road accidents should be part and parcel of the whole society and not only the government.

Orthopedic and Trauma Surgeon (OTS) from Iringa Referral Hospital reported that:

Poor families enter into the burden of borrowing money so as to take care of their relatives who are victims of road accidents to other referral hospital like Bugando, Muhimbili or KCMC.

In addition, the study revealed that there was a risk of spreading diseases like HIV/AIDS. Such disease is more transmitted due to blood contamination as a result of bleeding during road accidents. This may happen when the stains of HIV negative person contaminated with the blood of a person with HIV blood.

The study argues that destruction of transport facilities and economic bankruptcy lead to unemployment. The interview that was conducted with medical officer also proved that injuries and disabilities lead to unemployment, as he said;

......many victims of road accidents are suffering from severe bleeding, and this leads to paralysis and in many cases amputation of their vital body organs/parts; the loss of body organs reduces their employability and eligibility for being employed.

Furthermore, TANROADS staff reported that currently many people employed as drivers, motor cyclist and/or conductors lose their jobs in case they cause accidents, and income sources fade away, thus, they get depressed 
and paranoid. This concurs with what Dano (2005) and Mnzawa (2013) found as they argue that road accident negatively impacts both on human and socio-economy and the government in general especially when casualties are hospitalized under intensive care for long time.

According to access model, the impacts relating to such incidents affect adversely the poor, though in terms of property, they have very little to lose. The poor have limited capacity to cope with the disaster and when they are affected their capacity to reconstruct and come back to normal is a great challenge (Wisner et al., 2005; Haulle, 2014).

\section{The Intervention Measures on Road Accidents and its Challenges}

The study revealed that about $69 \%$ of respondents acknowledged there were several initiatives taken by government to curb this human induced disaster in Iringa municipality. This was also supported by RTO, OTS and Regional Manager TANROADS (RMT).The road improvements include the construction of road signs, periodical maintenance and upgrading the roads status from gravels to bitumen (Figure 5).
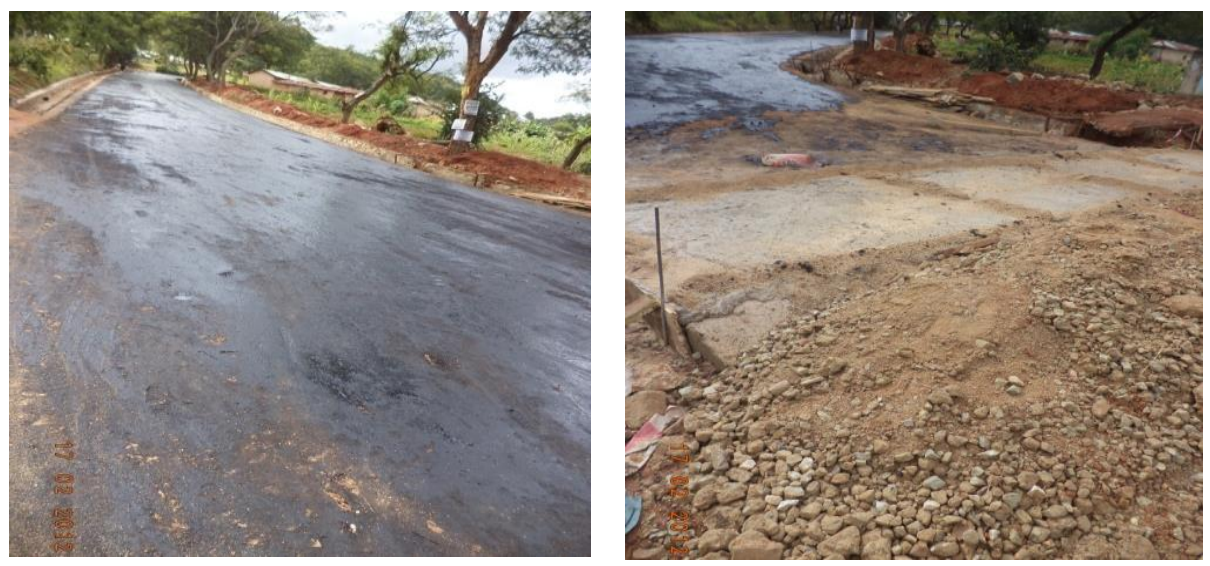

Figure 5: Pawaga road in Iringa Municipality under maintenance by upgrading it to bitumen level

Source: Field survey, 2015 
It was also revealed through interview with drivers that some of the upgraded roads are sub-standard. Some of the roads were so slippery when they are wet. The road section within Mikumi National Park was reported to be one of the poorest points after its maintenance in recent years. Installation of curve warning signs would lead to $20 \%$ average of accident reduction (Tignor, 1993; Molnar, 2010). Installation will remain functional to ensure safety objectives only if they are adequately maintained. It is recommended that the rehabilitation of roads should go hand in hand with public education on proper use of the road infrastructure. That is to say, roads infrastructure, should be wide to accommodate the increasing imported vehicles (Chiduo \& Minja, 2001).

In this regard, Chaturvedi (2006) and Tignor (1993) argue that education is one of the important factors which would play a kingpin in the long run to drastically reverse the graph of road accidents. Education helps individuals to play their positive roles in prevention of road accidents and prepare the responsible drivers. However, the current study found that majority of road users including civilians do not have the basic knowledge on proper road usage. This was pointed out by RTO who reported that the provision of education about road safety to the pedestrians and drivers hugely helped to reduce accidents. The education on road safety provided to people within Iringa Municipality through various local radio stations based in Iringa such as Ebony FM, Overcomers FM, Furaha FM, Country FM and Nuru FM helped to create public awareness on proper road usage (Figure 7). Education should be provided to people (road users) to raise consciousness among them and make them aware that wearing helmet, fastening seat belts should be compulsory for their own safety and not something optional as suggested by the police officer. This is because the current study found that many motor cyclists do not voluntarily wear helmet. Figure 6 shows how even the police who are aware and supposed to enforce the law infringes the law by not wearing the helmet.

It was acknowledged there is substantive effort made by National Road Safety Council of Tanzania, however, no clear and co-ordinated system of safety education, and it has never been a compulsory part of the school curricula in Tanzania (Chiduo \& Minja, 2001). The education would ensure that all road users, road managers, vehicle manufacturers have a shared 
responsibility to take appropriate actions and steps to end road accidents. Education on road safety should start in the school curriculum from Kindergarten to the higher learning institutions and should carry special issues in terms of assessments.

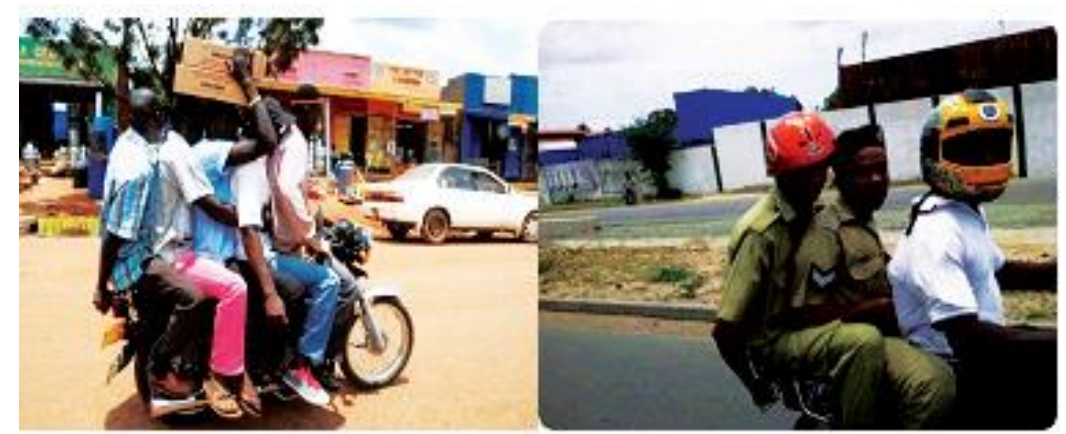

Figure 6. Both officers vested power to enforce laws and Civilians are not keen and committed to fight in reducing road accidents, in spite of the negative socioeconomic impacts of the accidents to the community.

Source: Legal and Human Right Centre (2013)

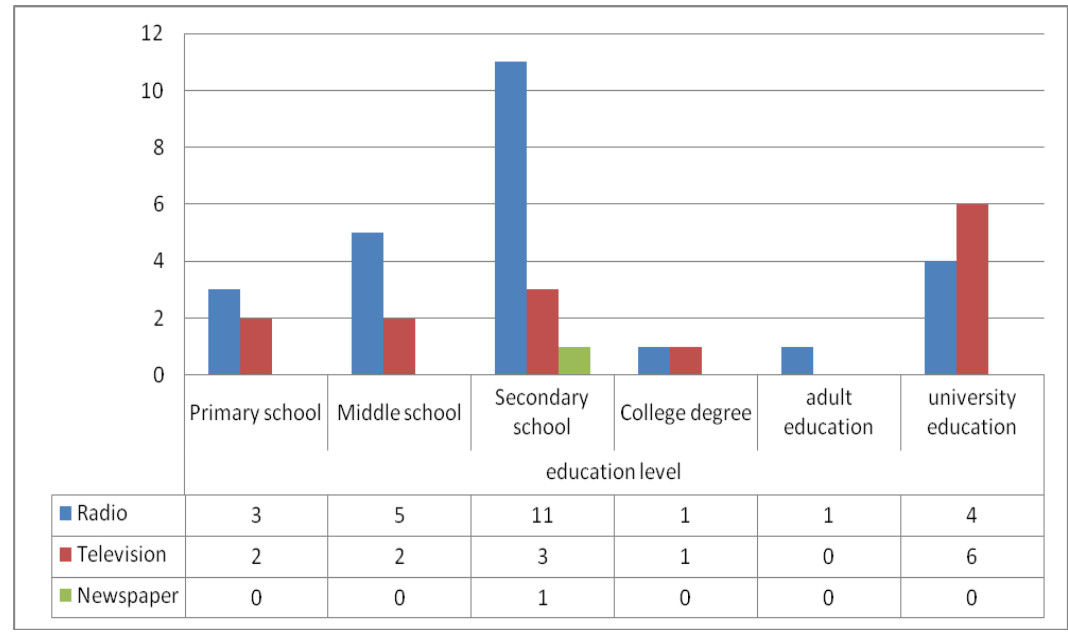

Figure 7: The level of education and the means of acquiring information on road accident in Iringa municipality. 
Introduction of regular inspections and patrol of transport facilities as suggested by many interviewee and questionnaire respondents of the current study. The regular inspections to a great extent would reduce the road accidents. Inspections would enhance quality of transport facilities, enforcing observance of driving rules and regulations. However, during the interview TANROADS officers accused people of stealing road traffic signs. They also accused drivers of stealing road traffic signs so as to be free from legal obligation imposed on them. Nevertheless, there is very little attention on the unofficial traffic signs used on the roads like tree branches and leaves that are not taken out after the emergency. Such tree branches/leaves contribute to the risk and vulnerability of road users. It was also noted that many traffic police do not inspect the vehicle safety. The police are noted to be busy with only controlling the speed without paying due regards on checking the mechanical setup of the vehicles. Most of them do inspect the compliance to the revenue charges and not safety.

I have been a driver for more than 15 years, but for more than six years now I have never been asked by the Police to test the brakes or light functions in the car. I have never been asked if my car has been regularly serviced; they are busy with hunting money not ensuring safety.

It is evident that regular inspections would ensure that part of vehicle which enhance safety reach the minimum standards of performance and vehicle that fails to meet standards must be stopped and called for legal proceedings. Road infrastructure and automobile inspections would also ensure regular maintenances of transport facilities, a decision that could reduce rate of accident incidents and reduce fatalities and injuries (Ross, 1991; Peden, 2004; Mnzawa, 2013).

According to National Disaster Management Policy of Tanzania, there should be disaster management committee at every administrative level (URT, 2004). However, it was evident that very little is implemented in disaster management (Haulle \& Rugumamu, 2015). The committee is not there, and whenever they are established, they only operate during the disaster and especially during famine (Haulle, 2007; Haulle, 2014). Moreover, these supposed committees have never acted to work with 
accident risk reduction in their areas of jurisdictions. Disaster management policy is among important frameworks for disaster management; when such documents are not used the disaster mitigation and risk reduction will remain pipe dream and the youth life will continue to be affected.

Strengthening the policy and legal system is also an important measure. The finding noted the legal system to be weak, too old with a serious weakness of alcohol enforcement act, blunt penalty ranging from $10,000 /=$ to $30,000 /=$. Also many police traffic officers are inherently interfered by politicians. It would also develop seriousness and commitment to all road users towards preventing road accidents. Legal system was also noted to be questionable, in terms of, inspection of vehicles abroad before they are imported as Tanzania is increasingly becoming a dumping place of even distorted equipment/facilities. It was also noted that there was no person in the current study whose car was rejected during inspection prior to the shipping. This suggests that this inspection is only for revenue collection not for human safety. It is a challenge for mitigating the accidents in Tanzania, thus, poses a question which the state should address to ensure human safety (cf. Haulle, 2014).

\section{Conclusions and Recomendations}

In general societies are faced with a great loss, in terms of, human, material and financial resources. The number of accidents so does the number of fatalities, injuries and damages of the property is increasing steadily causing the malfunctioning of families and community at large. Some of the damaged vehicles are not repaired; some are damaged beyond repair and replacement at the given economic conditions impossible. People become amputees of their organs. The intervention measures suggested were clearly noted to be on-site conditions that can only treat the problem superficially; they are like helicopter solution. The poor are highly affected than the rich people and there are so limited chances to connect the accident and the economic strength of the involved parties. This is because of the commonness of the ruling class. When they show signs of functioning as the last two years that showed a slight decline of the events does not guarantee their sustainability. This is the reason why after every catastrophic event, the control is becoming 
firm; the institutions are focusing on cure not mitigation. However, after a very short period of time everything is forgotten, hence, the next disaster is unfolded making the continuum of the disaster circles. Generally, the intervention taken to curb the problem is blunt and unreliable. It was found that there is unequal distribution of resources and negative relation between production and institutional set up and the link between the haves and the have not, the peasants, working / middle class and ruling class alarming. It is recommended that the state restores the economy that will benefit the majority.

The government in collaboration with private organization should prepare comprehensive programmes that will help the majority to transform them in psychomotor, cognitive and affective domains to fully participate in preventing, mitigating and fighting against the road accidents after improving the social relation in the community. In order to reduce the magnitude of road accidents traffic law must be amended; policies and institutional reforms are urgently needed to reform. Massive empowerment and capacity building is needed to both institutional framework that will be pro-majority and participatory in nature. Education is highly needed for the people to be aware of their rights and basic road traffic rules and regulations. This may raise awareness among the majority and, hence, reduce the road accident incidents by reporting drivers who misbehave on the road. Road traffic laws have to be enforced to ensure the problem gets to an end. Also, the use of modern alcohol tester should be used widely to make sure that the problem is diminishing.

There is also need to undertake a study on the relationship between the cause of accidents or those who commit traffic offences and the ownership of the of the motor vehicle in order to understand whether is a class issue or not and thus devise proper mechanisms for intervention.

\section{References}

Ary, D., Jacobs, L.C., Sorensen, C., \& Razavieh, A. (2010). Introduction to Research in Education ( $8^{\text {th }}$ Ed). New York: Wadsworth, Cengage Learning. 
Bashaya, P. (2015, February 21). Ajali. Mwananchi Communications. Retrieved from http://www.mcl.co.tz/mcl_blog/index.php

Boniface, R., Museru, L., Kiloloma, O., \& Munthali, V. (2016). Factors associated with road traffic injuries in Tanzania. The Pan African Medical Journal, 23(1). doi: 10.11604/pamj.2016.23.46.7487

Burns, N., \& Grove, S.K. (1987). The Practice of Research, Conduct, Critique and Utilization. Philadelphia: Saunders.

Chakrabarty, N., Gupta, K., \& Bhatnagar, A. (2013). A survey on Awareness of Traffic Safety among Drivers in Delhi-India. The SIJ

Transactions on Industrial, Financial and business management (IFBM), 1(2), 106-109.

Chatorvedi, P. (Ed.) (2006). Challenges of occupational safety and health thrust. Safety in transportation. New Delhi: Concept Publishing Company.

Chiduo.W.C., \& Minja, P. (2001). Road safety in Tanzania: What are the problems? Technology Transfer in Road Transportation in Africa, Arusha International Conference Centre, Tanzania, 23-25 May 2001.

Cohen, L., Manion, L., \& Morrison, K. (2007). Research Methods in Education ( $\left.6^{\text {th }} E d\right)$. London: Rutledge Publishers.

Cormack, D.S. (1991). The Research Process. Oxford: Black Scientific.

Creswell, J.W., \& Plano Clark, V.L. (2011). Designing and Conducting Mixed Methods Research. $2^{\text {nd }}$ edition. London: Sage Publication.

Danø, A.M. (2005). Road Injuries and Long-Run Effects on Income and Employment. Health Economics, 14(9), 955-970. doi:

10.1002/hec.1045

Dawnson, C. (2007). Practical Research Metdhos: A User-friendly Manual for Mastering Research Technique and Projects $3^{\text {rd }}$ Ed.) Oxford: How to Books.

Duffy, M.E. (1985). Designing Nursing Research: The QualitativeQuantitative Debate. Journal of Advanced Nursing, 10(3), 225-232. doi: 10.1111/j.1365-2648.1985.tb00516.x

Haulle, E. (2007). The Role of Traditional Environmental Knowledge Systems in the Earthquake Disaster Management in Ludewa District, Tanzania. Unpublished Dissertation. MA in Geography And Environmental Management, University of Dar es Salaam. 
Haulle, E. (2012). Evaluating Earthquake Disaster Risk Management in

Schools in Rungwe Volcanic Province in Tanzania. Jàmbá. Journal of

Disaster Risk Studies, 4(1). doi: 10.4102/jamba.v4i1.44

Haulle, E. (2014). Assessment of Communities' Coping mechanisms to Geodisaster Risks in the Vicinity of Oldoinyo Lengai in Northern Tanzania. PhD Thesis, University of Dar es Salaam.

Haulle, E. (2015). Land Resource in Tanzania: Whose State, Whose Resource? International Journal of Social Science Studies, 3(6), 70-78. doi: 10.11114/ijsss.v3i6.1102

Haulle, E., \& Rugumamu, W. (2015). Linking School Environment to Geodisaster Risk Reduction for Sustainable Development in Tanzania. Journal of Humanities Social Sciences and Education, 2(6), 91-98.

Legal and Human Right Centre (2013). Tanzania Human Right report. Dar es Salaam: Legal \& Human Right Center.

Komba, D.D. (2006). Risk Factors and Road Traffic Accidents in Tanzania. A Case of Kibaha District. Oslo: Norwegian University of Science and Technology (NTNU).

Kothari, C.R. (2014). Research Methodology. Methods and Techniques $3^{\text {rd }}$ Ed. New Delhi: New Age International Publishers.

Lay, M.G. (1986). Handbook of Road Technology, 2 volumes. London: Gordon and Breach.

Majinge, B., \& Mwafongo, H. (2015, March 12). Nation's shock as horror smash kills 42. The Citizen. Retrieved from http://www.thecitizen.co.tz/News/Nation-s-shock-as-horror-smashkills-42/1840340-2650420-13br9br/index.html

Medi, B. (2014). Global Vehicle Overload Madness. Shanghai Metal Corporation. Retrieved from https://shanghaimetalcorporation.wordpress.com/2014/08/14/globalvehicle-overload-madness/

Ministry of Road Transport and Highways Government of India (2011). Road accidents in India. Issues \& Dimensions.

Mnzawa, E.G. (2013). The Impacts of Motorcycle Accidents in Tanzania. A Case Study of Morogoro. Tanzania. Mzumbe University.

Molnar, E. (2010). Consolidation Resolution on Road Traffic. New York: United Economic Commission for Europe. 
Morphy, M. (2011). Design and Contraction of Road and Accesses to Adoptable Standards. London: Transportation Development Advice.

Mubiru, S. (2013). Mv islander charge sheet cites 2.740 casualities in the world's worst maritime disaster. 24 Tanzania. Retrieved from http//:24tanzania.com

Oliver-Smith, A., \& Hoffman, S.A. (1999). The angry earth: disaster in Anthropological perspective. New York: Routledge.

Peden, M. (2008). World report on child injury prevention. Geneva: World Health Organization.

Peden, M. et al. (2004). World Report on Road traffic injury prevention. Geneve: World Health Organization.

Pinard, M.L. (2010). Guidelines on Vehicle Overload in Eastern and Southern Africa. Botswana: The International Bank for Reconstruction and Development.

Raffo, V., \& Bliss, T. (2012, December). The Decade of Actions for road safety 2011-2020: Lesson from Argentina and Caribbean region (LAC). En Breve, 180.

Richard, S. (2004). World Report on Road Traffic Injury Prevention. Geneva: WHO.

Robertson et al. (2009). UN-General assembly of the 2010-2020 Make Road Safe-Global Decade of action for road safety.

Rodriguez, J.I. (2005). El reto de sobrevivir. Tráfico.

Ross, R. (1991). Towards Safer Roads in Developing Countries. Crowthorne: Transport Research Laboratory.

Sauter, C.S., Zhu, S., Allen, S., Hargaten, S., \& Layde, P.M. (2005). Increased risk of death or disability in unhelmeted Wisconsin Motorcyclists. Wisconsin Medical Journal, 104(2), 39-44.

Sauwa, S. (2015, February 20). Lori la mafuta lapinduka lauwa watatu Mbeya. Mwananchi. Retrieved from http://www.mwananchi.co.tz/habari/Kitaifa/Lori-la-mafuta-lalipuka-laua-watatu-Mbeya/1597296-2629708-12i1877z/index.html

Singh, K. (2007). Quantitative Social Research Methods. New Delhi: SAGE Publication. 
Shivji, I.G. (2005). Lawyers in Neoliberalism: Authority's Professional Supplicants or Society's Amateurish Conscience. Dar es Salaam: Faculty of Law, University of Dar es Salaam.

Surface and Marine Transport Regulatory Authority (SUMATRA) (2007). Study on road accident in main land Tanzania. Dar- es-Salaam:

Bureau for Industrial Cooperation (BICO), University of Dar es Salaam.

Surface and Marine Transport Regulatory Authority (SUMATRA) (2012).

Document details/study on road accident in mainland Tanzania. Dares-Salaam: Bureau for Industrial Cooperation (BICO), University of Dar es Salaam.

Taft, C. (2002). Childhood unintentional injury worldwide: meeting the challenge. Washington, DC: Safe Kids Worldwide.

Thagesen, T. (2005). Highway Traffic Engineering in developing countries. London: Taylors \& Francis.

Tignor, S.C. (1993). Traffic Control Devices: Overview in the Traffic Safety toolbox. A primer on Traffic Safety. Washington, DC: Institute of Transportation Engineers.

UN-Habitant (2007). Enhancing Urban Safety and Security. London: Earth Scan.

United Republic of Tanzania (URT) (1993). Report on Road Traffic Law. Dar es Salaam: URT.

United Republic of Tanzania (URT) (2004). National Disaster Management Policy. Dar es Salaam: Tanzania Prime Minister's Office.

United Republic of Tanzania (URT) (2009). National Road safety Policy. Dar es Salaam: Tanzania Ministry of Works.

United Republic of Tanzania (URT) (2008). The Highway Code. Dar es Salaam: Ministry of Infrastructure Development.

Wisner, B., Blaikie, P., Cannon, T., \& Davis, I. (2005). At Risk: Natural Hazards, People's Vulnerability and Disasters. London: Routledge.

Wisner, B., \& Gaillard, J.C. (2009). An introduction to neglected disasters. Jàmbá. Journal of Disaster Risk Studies, 2(2), 151-158. doi: 10.4102/jamba.v2i3.23

World Bank (2014). Making Roads Safer: Learning from the world Banks' Experiences. Washington DC: World Bank Group. 
World Health Organization (WHO) (1986). International Classification of Impairments: Disabilities and handicaps. Geneva: WHO.

World Health Organization (WHO) (2013). Global Status Report on Road Safety: Supporting A Decade of Action. Geneva: WHO.

Evaristo Haulle is lecturer at Mkwawa University College of Education, Tanzania

Marwa Kisiri is a graduate at Mkwawa University College of Education, Tanzania

Contact Address: P.O. Box 2513, Iringa. Email: haulledict@gmail.com 